Bangladesh J. Zool. 42(1): 117-122, 2014

\title{
DEVELOPMENT OF A CULTURE TECHNIQUES FOR TUBIFICID WORM, UNDER LABORATORY CONDITIONS
}

\author{
M. Begum*, P. Noor, K. N. Ahmed, N. Sultana, M. R. Hasan and L. C. Mohanta \\ Zoology Section, BCSIR Dhaka Laboratories, Dhaka-1205, Bangladesh
}

\begin{abstract}
Study has been conducted to establish a suitable culture technique for Tubificid worm, Tubifex tubifex using different culture media. Cowdung, Rawfish and vegetables were evaluated as culture medium. Each medium was supplied as supplementary food at the rate of $250 \mathrm{mg} / \mathrm{cm}^{2}$ per week for 145 days. Water temperature, $\mathrm{pH}$ and ammonia of the rearing media ranged from $27.1-31.67^{\circ} \mathrm{C}$, 5.76-7.35 and $0.5-<2.5 \mathrm{mg} / 1$ respectively. Among the three media, the worms grew well in size in the cowdung medium whereas rawfish showed a moderate growth of worms with remarkable number of new generation of worms. There was no significant growth of worms in the vegetables. The collection of Tubifex was quite difficult but highest amount was in cow dung $(8.192 \mathrm{mg} / \mathrm{g})$, moderate in rawfish medium $(4.14 \mathrm{mg} / \mathrm{g})$ and lowest in the vegetables $(2.43 \mathrm{mg} / \mathrm{g})$. Cowdung medium showed the maximum growth in this study period which is more viable, easy and economical.
\end{abstract}

Key words: Culture techniques, Tubificid worm, Laboratory conditions.

\section{INTRODUCTION}

Intensive fish culture in Bangladesh is greatly hampered by crucial curtail of essential feed ingredients. Live feed organisms are performed by most of the cultured larvae compared to artificial feed (Sorgeloos 1979, Immanuel et al. 2001). The quality seeds of catfishes are mostly dependent on proper feed management in which production of live foods particularly the tubificid worms in rearing catfish larvae is important (Hossain et al. 2011) Live food organisms like Daphnia sp. (Marian and Chandran 1989) and Artemia (Dwivedi et al. 1980, Basil et al. 1987; Marian et al. 1991, Marian, 1993) have been cultured using organic waste like cowdung, poultry manure, cabbage wastes, coconut mesocarp waste and pig dung in order to reduce the production cost as well as to utilize the waste for food production.

Tubificid, commonly known as sludge worm is one of the cosmopolitan freshwater oligochaetes that plays an important role as supplementary food (live or freeze dried) in aquaculture. This oligochaeta worm, Tubifex sp. is one of the best and cheapest live feed for fish, prawns and frogs (Marian and Pandian 1984). It has been reported to be an important live feed in rearing the larvae of

*Author of correspondence: <panna_mahmuda@yahoo.com>. 
hatchery produced catfishes, prawns, ornamental fishes etc. (Hossain et al. 2011.). Significantly higher survival rates and 10 times additional growth rates were recorded in $C$. batrachus larvae fed with tubificid worms over those formulated dry feed (Alam and Mollah 1988). Tubificid worms are very important to freshwater intensive aquaculture particularly because of their high food values (5575 cal g-1 on a dry weight basis (Giere and Pfannkuche 1982).

In Bangladesh, the current supply of these worms obtained from wild harvests which are unreliable and inadequate in terms of demand. Little success has been reported of attempts taken to develop a technique for tubificid worms culture (Mollah and Ahamed 1989, Ahamed and Mollah 1992). For this reason, it is very important task to develop a compatible culture medium for commercial production of Tubifex sp. as an inexpensive alternative to other commercial feeds needed for fish rearing. Therefore, the objectives of the present study were to make a comparative analysis on different culture media and to find out the most suitable food medium for optimal growth of Tubifex sp.

\section{MATERIAL AND METHODS}

The experiments were conducted over a period of 145 days (from March 2012 to August, 2012) in experimental beds at the Zoology Section, BCSIR Laboratories, Dhaka. At first, Tubificid worms were collected from local drains of BCSIR and cleaned by water flow and held in a water flow-through-system for $24 \mathrm{hrs}$. The worms were cultured in rectangular plastic containers of a particular size of $42 \mathrm{~cm} \times 32 \mathrm{~cm} \times 20 \mathrm{~cm}$ with continuous water flow, adjusted through the plastic pipes. Three different types of culture media with three replicates for each treatment were maintained. The media were cowdung $(70 \%$ cowdung: $30 \%$ field soil), rawfish (20\% raw fish slice: $80 \%$ soil) and vegetables $(70 \%$ blended vegetables matter of kitchen garbage: $30 \%$ soil). The ingredients of all media were mixed with water and kept for 4 days to enhance decomposition. The same media were supplied as supplementary food in each container at the rate of 250 $\mathrm{mg} / \mathrm{cm}^{2}$ once in every 10 days. Culture media were placed and adjusted 24 hours before inoculation of worms to the media. On the second day, about $1.5 \mathrm{~g}$ of tubifex worms were introduced at the rate of $1.09 \mathrm{mg} / \mathrm{cm}^{2}$ and spread homogeneously over the media. About $10 \mathrm{~g}$ of samples were randomly collected from each media by a sampling spatula $(2 \mathrm{~cm} \times 2 \mathrm{~cm})$ once in every 10 days. After washing, the weights of cleaned worms were weighed through electric balance (Model: AND, GR-200, Japan). Water temperature, $\mathrm{pH}$ (Oyster portable $\mathrm{pH}$ meter, pp-201, Taiwan), Ammonia (determined by a calorimetric method, APHA, 1985) of the culture media were recorded once in every 3 days. The statistical analysis of different physico-chemical parameters were carried out by using one- 
way ANOVA and any difference at 5\% level of significance by using the statistical package of SPSS-16 to express the results.

\section{RESULTS AND DISCUSSION}

The growth of tubifex worms varied with medium during different experiments conducted (Table 1). The highest average weight of tubifex worms was recorded in cowdung medium having $73.0 \pm 56.83 \mathrm{mg} / 10 \mathrm{~g}$ whereas medium with vegetables exhibited the lowest weight of $26.35 \pm 37.86 \mathrm{mg} / 10 \mathrm{~g}$ on an average. Medium with rawfish showed moderate growth rate in case of weight $(44.83 \pm 33.25 \mathrm{mg} / 10 \mathrm{~g})$ but the highest rate $(48.50 \pm 26.63$ individuals $/ 10 \mathrm{~g})$ in case of numbers of new generation. The medium containing vegetables showed lowest rate of growth in numbers of new generation $(0.41 \pm 0.90$ individuals/10g) (Table 1). It is apparent that there was a significant positive relationship $(r=0.875)$ between the numbers of new generation and weight of worms in vegetable culture medium (Tables 2 and 3 ).

Table 1. Average temperature $\left({ }^{\circ} \mathrm{C}\right)$, $\mathrm{pH}$, ammonia $(\mathrm{mg} / 1)$, weight $(\mathrm{mg} / 10 \mathrm{~g})$ and numbers of new generation of Tubifex sp. in different culture media

\begin{tabular}{|c|c|c|c|c|c|}
\hline Culture media & $\begin{array}{l}\text { Temperature } \\
\left({ }^{\circ} \mathrm{C}\right) \\
(\text { Mean } \pm \mathrm{SD})\end{array}$ & $\begin{array}{c}\mathrm{pH} \\
(\text { Mean } \pm \mathrm{SD})\end{array}$ & $\begin{array}{c}\text { Ammonia } \\
(\mathrm{mg} / \mathrm{l}) \\
(\mathrm{Mean} \pm \mathrm{SD})\end{array}$ & $\begin{array}{l}\text { Weight }(\mathrm{mg} / 10 \mathrm{~g}) \\
\quad(\text { Mean } \pm \mathrm{SD})\end{array}$ & $\begin{array}{l}\text { Number of new } \\
\text { generation } \\
\text { (Indi./10g) } \\
\text { (Mean } \pm \text { SD) }\end{array}$ \\
\hline Cowdung (MC) & $29.77 \pm 1.3^{a}$ & $6.92 \pm 0.25^{\mathrm{a}}$ & $2.0 \pm 0.518^{a}$ & $73.0 \pm 56.83^{a}$ & $5.33 \pm 3.05^{b}$ \\
\hline Raw Fish (MF) & $29.30 \pm 1.35^{\mathrm{a}}$ & $6.98 \pm 0.24^{a}$ & $1.39 \pm 0.40^{\mathrm{b}}$ & $44.83 \pm 33.25^{\mathrm{ab}}$ & $48.50 \pm 26.63^{a}$ \\
\hline Vegetables (MV) & $29.42 \pm 1.44^{a}$ & $6.73 \pm 0.43^{a}$ & $1.92 \pm 0.64^{a}$ & $26.35 \pm 37.86^{b}$ & $0.41 \pm 0.90^{\mathrm{b}}$ \\
\hline
\end{tabular}

Means having the same letters in column do not differ significantly at $5 \%$ level of significance.

\begin{tabular}{lcccc}
$\begin{array}{l}\text { Table 2. Correlation between weight and } \\
\text { generations }\end{array}$ & pemperature & $\mathrm{pH}$ & Ammonia & $\begin{array}{c}\text { Number of new } \\
\text { generation }\end{array}$ \\
\hline Culture media & Temperature, ammonia and number of \\
\hline Cowdung & -0.432 & 0.213 & -0.339 & 0.159 \\
Raw Fish & -0.172 & -0.384 & -0.025 & 0.249 \\
Vegetables & 0.027 & -0.317 & -0.160 & $0.875^{* *}$ \\
\hline
\end{tabular}

*Significant at the 0.05 level (2-taited), ** Significant at the 0.01 level (2-tailed).

There was no significant difference among the physico-chemical parameter viz. temperature (F-0.550, p>0.581), $\mathrm{pH}(\mathrm{F}-2.224, \mathrm{p}>0.122)$ and ammonia $(\mathrm{F}-$ $5.457 \mathrm{p}>0.008)$ of three culture media on growth $(\mathrm{F}-4.580, \mathrm{p}>0.018)$ and number of new generation worms $(\mathrm{F}-34.203, \mathrm{p}>0.000)$. The recorded average temperature and $\mathrm{pH}$ were more or less similar but ammonia showed little variation in all the 
media. Under study, water temperature ranged from $26.62^{\circ} \mathrm{C}$ to $31.66^{\circ} \mathrm{C}$. There was an insignificance difference between the number of new generation and temperature of the three culture media. The relationship between mean ammonia level and number of new generation worms of cowdung media shows statistically positive relationship at $5 \%$ level of significance (Table 3). The average $\mathrm{pH}$ values were between $6.73 \pm 0.43$ to $6.98 \pm 0.24$. It was found that $\mathrm{pH}$ of the rawfish medium indicated a significant negative relationship ( $\mathrm{r}=-0.583)$ with the growth of new generation worms (Table 3).

Table 3. Relationships between number of new generation and $\mathrm{pH}$, temperature, ammonia, weight

\begin{tabular}{lcccc}
\hline Culture media & Temperature & $\mathrm{pH}$ & Ammonia & Weight \\
\hline Cowdung & 0.181 & -0.099 & $0.579^{*}$ & 0.159 \\
Raw Fish & 0.491 & $-0.583^{*}$ & 0.290 & 0.249 \\
Vegetables & 0.177 & -0.451 & -0.039 & $0.875^{* *}$ \\
\hline
\end{tabular}

* Significant at the 0.05 level (2-taited), ** Significant at the 0.01 level (2-tailed).

Figure 1 shows that the comparative effects of three cultured media on the tubifex throughout the experiment. In cowdung medium, the weight of worms showed remarkable fluctuation of increase and decrease with the higher yield on

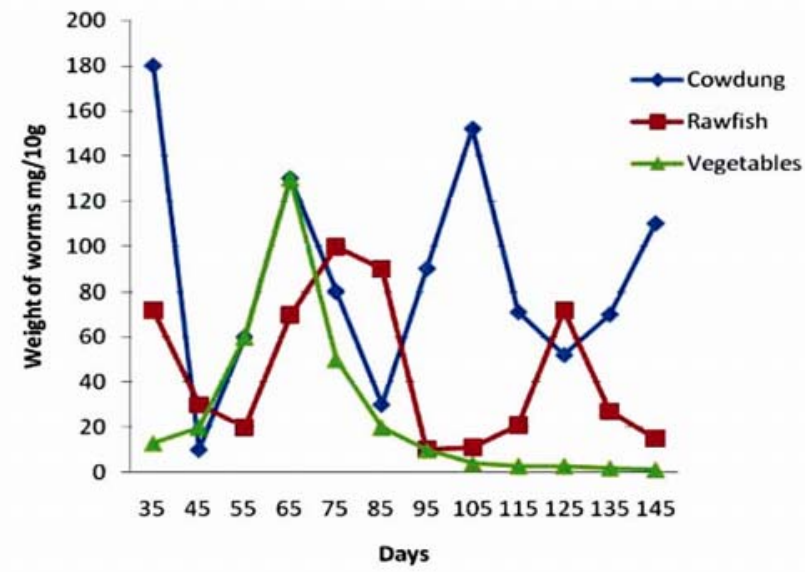

Fig. 1. Effects of culture media on the growth (weight) of Tubifex worms under study period.

the $65^{\text {th }}$ and $105^{\text {th }}$ days whereas lowest on the $45^{\text {th }}$ and $85^{\text {th }}$ day's record (Figure 1). In rawfish medium, the weight of worms showed irregular pattern with slight decrease on the $55^{\text {th }}$ day before reaching at optimum growth on the $75^{\text {th }}$ day of sampling and then decreased on the $95^{\text {th }}$ and $105^{\text {th }}$ day with slight increase on the $125^{\text {th }}$ day. The growth of worms in vegetable medium attained a peak on the $65^{\text {th }}$ day and then decreased sharply to the lowest growth rate $(1.3 \mathrm{mg} / 10 \mathrm{~g})$. 
The effect of culture media on the number of new generations of Tubifex worms is found in Figure 2. The highest growth rate was found in medium having rawfish upto 82 individuals $/ 10 \mathrm{~g}$ on the $85^{\text {th }}$ day of culture which gradually decreased to 12 individuals $/ 10 \mathrm{~g}$. On the other hand, cowdung and vegetable media exhibited more or less similar trends during study period i.e. fewer numbers of progeny produced. The least number (0-1/sample) of offspring was noticed in vegetable based medium.

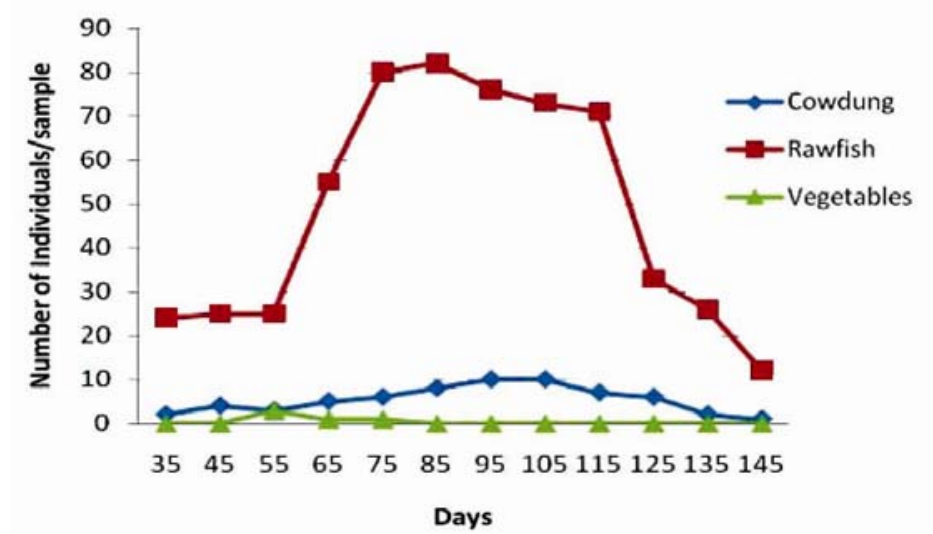

Fig. 2. Effects of culture media on the growth (number of new generation) of Tubifex worms.

The observed highest yield $936 \mathrm{mg} / 120 \mathrm{~g}$ sample was observed in 145days sampling containing $70 \%$ cowdung and $30 \%$ sand. The lower yield $(316.3$ $\mathrm{mg} / 120 \mathrm{~g}$ sample) in vegetable medium might be because of their less suitability as a culture medium. Marian and Pandian (1984) reported yield of $1 \mathrm{~g}$ worms using $2.85 \mathrm{~g}$ media ingredients of $75 \%$ cowdung and $25 \%$ sand which is conformity with that of cowdung medium.

The temperature of water in culture media ranged from $27.5^{\circ} \mathrm{C}-31.67^{\circ} \mathrm{C}$ in cowdung medium; $27.1^{\circ} \mathrm{C}-31.66^{\circ} \mathrm{C}$ in rawfish medium and $26.62^{\circ} \mathrm{C}-31.66^{\circ} \mathrm{C}$ in vegetable medium. Randall et al. (2011) reported that the optimal culture conditions i.e., temperature, density, and feed type etc were unknown for $T$. tubifex. He recorded the performance of worms fed on cow manure was poor and its growth and recruitment were best when they were supplied with a commercial fish-flake food (Tetramin) or a commercial sinking fish feed having Spirulina sp.

Hossain et al. (2011) reported that the highest yield of worms (659.35 \pm $16.88 \mathrm{mg} / \mathrm{cm}^{2}$ ) was detected after $70^{\text {th }}$ day of sampling over 80 days duration in optimum culture media containing a mixture of $30 \%$ soybean meal, $20 \%$ mustard oil-cake and $10 \%$ sand in combination with a fixed ratio of $20 \%$ wheat bran and $20 \%$ cowdung 
Therefore, the supply of Tubifex worms for fish culture specially aquarium fishes could be increased by using the cowdung medium through large scale production beds. More intensive study is needed for the development of precise method for sustainable production of this worm on commercial range.

\section{LITERATURE CITED}

AHAMED, M.T. and MOLLAH, M.F.A. 1992. Effects of various levels of wheat bran and mustard oil cake in the culture media on Tubificid production. Aquacul. 107:107-113.

ALAM M. S. and MOLLAH, M.F.A. 1988. Formulation of an artificial dry feed for primary nursing of catfish (Clarias batrachus L) larvae. Bang. J. Fish. 11: 71-75.

BASIL, J.A., PREMKUMAR, D.R.D., LIPTON, A.P. and MARIAN, M.P. 1987. Preliminary studies on the culture of Artemia salina using renewable organic wastes. In: Artemia research and its applications. Vol. 3 Ecology, culturing and use in aquaculture (Eds. P. Sorgeloos, D. A. Bengston, W. Decleir and E. Jasper). Univ. press, Wetteren, Belgium, pp. 275-278.

DWIVEDI, S.N., ANSARI, S.K.R. and AHEMED, M.Q. 1980. Mass culture of brine shrimp under controlled conditions in cement pools at Bombay, India, In: Artemia research and its applications. Vol. 3 Ecology, culturing and use in aquaculture (Eds. P. Sorgeloos, D. A. Bengston, W. Decleir and E. Jasper). Univ. press, Wetteren, Belgium, pp.175-183.

GIERE, O. and PFANNKUCHE, O. 1982. Biology and ecology of marine oligochaeta a review. In: $M$. Barnes (ed.), oceanography and Marine Biology, Aberdeen University press, pp.173-308.

HOSSAIN A., HASAN M. and MOLLAH M.F.A. 2011. Effects of Soyabean Meal and Mustard Oil-cake on the Production of Fish Live Food Tubificid Worms in Bangladesh. W.J. Fish and Marine Sci. 3(3): 183-189.

IMMANUEL, G., PETER MARIAN, M. and PALAVESAM, P. 2001. Effect of feeding lipid enriched Artemia nauplii on survival, growth, tissue fatty acids and stress resistance of postlarvae P. indicus. J. Asian Fish. Science, 14(4): 377-388.

MARIAN, M.P. and CHANDRAN, S. 1989. Chironomus, In: Manual on culture organism for prawn (Eds). T. J. Pandian and M. P. Marian, MPEDA publication, Cochin, India, pp. 62-76.

MARIAN, M. P., PUNITHA, M.J. and BABU, M.M. 1991. Anaerobic treatment of cow dung, poultry manure and cabbage. (Abstract) Proc. International Conference on Food Resources, Production and Processing, M.K. University, December 2nd to 5th 1991.

MARIAN, M.P. 1993. Artemia cultivation Technology, In: Live Feed. MPEDA Publication, Cochin, India, pp. 31-44.

MARIAN M.P. and T. J. PANDIAN. 1984. Culture and harvesting techniques for Tubifex tubifex. Aquacul. 42(3-4): 303-31.

MOLLAH, M.F.A. and AHAMED, M.T. 1989. A note on preliminary study of culture of Tubificids Worms. Bang. J. Fish.12: 91-95.

RANDALL W.O., MATT, B. and ERIC, J.W. 2011. Culture of Tubifex tubifex: Effect of Feed Type, Ration, Temperature, and Density on Juvenile Recruitment, Production, and Adult Survival. $N$. Amer. J. Aquacul. 73(1): 68-75.

SORGELOOS, P. 1979. The brine shrimp Artemia salina, A bottle neck in Mariculture In: FAO Technical conference on Aquaculture. T. Kyoto, T.V.R. Pillay, T.V.R. and W.A. Dill (Eds.) Fishing News Books Ltd., Farnham, England, pp. 653. 